\title{
Upaya Peningkatan Keterampilan Menyimak Pidato Persuasif dengan Menggunakan Konsep Peta Pikiran
}

\author{
Arif Wahyu Syarifullah*
}

MTS Negeri 9 Kuningan Kabupaten Kuningan Jawa Barat, Indonesia

A R T I C L E IN F O

Article history:

Received 19 August 2020

Received in revised form

30 September 2020

Accepted 10 October 2020

Available online 29

November 2020

\section{Kata Kunci:}

Bahasa, Keterampilan

Menyimak, Metode Peta

Pikiran

Keywords:

Language, Listening Skills, Mind Map Method

A B S T R A K

Penelitian ini bertujuan untuk mengetahui peningkatan keterampilan menyaimak pidato persuasive dengan menggunkan konsep peta pikiran. Penelitian ini berbentuk PTK terdiri dari 3 Siklus dengan subyek penelitian kelas IX dengan subyek sejumlah 38 siswa. Berdasarkan data hasil penelitian yang telah penulis lakukan maka dapat disimpulkan sebagai berikut (a) kemampuan siswa menentukan hal-hal pokok pidato dan ceramah dari $49,20 \%$ meningkat menjadi $76,80 \%$.(b) kemampuan siswa menentukan isi pidato dari $49,60 \%$ meningkat menjadi $76,00 \%$.(c) kemampuan siswa menyimpulkan pesan isi pidato dari 50,68\% meningkat menjadi 74,80\%.(d) kemampuan siswa mengomentari isi pidato dan ceramah dengan alasan-alasan yang logis dan bahasa yang santun dari 52,80\% meningkat menjadi $71,40 \% .2$ ) sikap siswa dalam menyimak umumnya lebih baik dan benar Dari hasil penelitian dapat ditarik kesimpulan sebagai berikut:1) pelaksanaan tindakan sebagai upaya meningkatkan keterampilan menyimak siswa kelas IX C MTs Negeri 9 Kuningan tahun pelajaran 2019/ 2020 semester ganil dengan teknik peta pkiran telah dapat meningkatkan prestasi keterampilan menyimak siswa. Siswa lebih mudah melakukan kegiatan menyimak.

\section{A B S T R A C T}

In general the problem of this research can be formulated as follows: "1) How are efforts to improve listening skills to persuasive speech using the concept of mind maps in eleventh grade students of MTs Negeri 9 Kuningan, Kabupaten Kuningan, West Java province for the 2019/2020 academic year, how to increase listening skill to persuasive speeches by using the mind mapping concept in eleventh grade students of MTs Negeri 9 Kuningan, Kabupaten Kuningan, West Java Province for the 2019/2020 academic year. This research was in the form of PTK consist of 3 cycles with the eleventh-grade research subjects of MTs Negeri 9 in first semester of the 2019/2020 academic year with 38 students as subjects. From the results of the study, the following conclusions: 1) the implementation of the action as an effort to improve the listening skills of eleventh grade students of MTs Negeri 9 Kuningan for the 2019/2020 academic year in first semester through the mind mapping technique has been able to improve students' listening skills. Students find it easier to do listening activities. Based on the research data, it can be concluded (a) the ability of students to determine the main points of speech increased from $49.20 \%$ to $76.80 \%$. (B) the ability of students to determine the speech content from $49.60 \%$ increased to $76.00 \%$. (c) the ability of students to conclude speech message content from $50.68 \%$ increased to $74.80 \%$. (d) the ability of students to comment on the speech content with logical reasons and polite language from $52.80 \%$ increased to $71.40 \% .2)$ The students' attitudes in listening were generally better and correct. Students can listen more concentrated way because of the mind mapping technique. 


\section{Pendahuluan}

Bahasa merupakan sarana komunikasi manusia dalam berinteraksi di masyarakat. Bahasa juga berperan penting dalam kehidupan yang sudah semakin berkembang. Menurut (Zakiyah, 2018) keterampilan berbahasa merupakan keterampilan yang dimiliki oleh setiap manusia. Keterampilan berbahasa yakni mengolah pesan diantaranya menyimak, berbicara, membaca dan menulis. Pada era seperti inilah keterampilan berbahasa membaca, menulis, menyimak, dan berbicara memiliki peran yang sangat penting. Peran tersebut adalah di era kompetitif ini keterampilan yang berkaitan dengan kompetensi individu menjadi kunci utama untuk mengikuti persaingan dalam dunia kerja maupun dunia luar. Menurut (Pebriana, 2017) Kurikulum 2013 menguraikan tujuan pembelajaran yang sejalan dengan tujuan pembelajaran bahasa Indonesia, yakni agar siswa terampil berbahasa. Keterampilan berbahasa dibedakan dari empat macam, yaitu menyimak, berbicara, membaca, dan menulis. Keempat keterampilan berbahasa tersebut berkaitan antara satu dan yang lain. Beberapa praktisi masih berpendapat sampai sekarang bahwa pembelajaran bahasa adalah sebuah proses yang berjalan linera/ lurus, yaitu diawali dengan menguasai bahasa lisan (menyimak dan berbicara) dan baru kemudian beralih ke bahasa tulis (membaca dan menulis).

Dari keempat keterampilan tersebut terdapat satu keterampilan yang sangat penting untuk berkomunikasi reseptif. Yakni Keterampilan menyimak merupakan salah satu keterampilan yang penting untuk komunikasi dan paling sering diabaikan oleh kita padahal kehidupan kita sangat didominasi oleh kegiatan menyimak. Keterampilan menyimak merupakan salah satu keterampilan berbahasa yang memiliki pengaruh langsung terhadap keterampilan bahasa lainnya, seperti berbicara, membaca, dan menulis. Hal ini seperti dikatakan (Tarigan, 1996) bahwa latihan menyimak akan mengakibatkan pengembangan dan peningkatan keterampilan bahasa lainnya. Menyimak merupakan dasar bagi proses pembelajaran bahasa yang akan mendorong keterampilan lainnya.

Paul T Rakin, dalam (Tarigan, 1996) menyatakan bahwa penggunaan waktu berkomunikasi seseorang adalah sebagai berikut: menulis (9\%), membaca (16\%), berbicara (30\%) dan menyimak (45\%). Dengan demikian, keterampilan menyimak sangat berpengaruh terhadap proses pembelajaran siswa. Namun, pelaksanaan pembelajaran menyimak sangat jarang dilaksanakan oleh guru. Hal ini sejalan dengan pernyataan (Satria, 2017) Kondisi peserta didik dalam kegiatan menyimak saat ini cukup memprihatinkan, keterampilan menyimak menjadi hal yang tidak diperhitungkan dan tidak tidak dianggap penting dibandingkan dengan keterampilan lainnya. Hal ini didukung oleh pendapat Dadan Djuanda (dalam bukunya pembelajran keterampilan berbahasa Indonesia di sekolah dasar).

Menurut (Hadi, 2017) Belajar-mengajar merupakan kegiatan yang mengaktifkan siswa dalam membangun makna atau pemahaman. Namun dalam pemikiran praktisi pendidikan, makna dan hakikat belajar sering kali hanya diartikan sebagai penerima informasi dari sumber informasi (pendidik dan buku bahan ajar). Akibatnya kebanyakan guru dalam kegiatan belajar mengajar masih sebagai sarana tokoh transfer informasi kepada siswa yang mengakibatkan anak didik menjadi malas belajar dan cenderung pasif pada kegiatan belajar-mengajar. Inti sebenarnya bahwa dalam tujuan pembelajaran siswa diwajibkan aktif, kreatif, mandiri, terampil dalam memecahkan masalah maupun dalam mengambil keputusan, percaya diri, serta siswa diharapkan ada kemampuan bersosialisasi dengan teman-temannya Berdasarkan hasil observasi di Kelas IX C MTs Negeri 9 Kuningan kemampuan menymak teks pidato persuasive siswa kelas tersebut masih kurang. Siswa masih kesulitan untuk menyimak teks pidato yang baik dan benar. Hal ini dibuktikan dengan nilai siswa yang masih berada di bawah rata-rata KKM sekolah yaitu 75.

Hal tersebut disebabkan oleh faktor internal dan faktor eksternal. Faktor internal, yaitu faktor yang berasal dari siswa itu sendiri, misalnya siswa kesulitan memahami gagasan yang disampaikan penuutrur atau penulis teks pidato. Selain itu, siswa juga masih mengalami kesulitan dalam memilih kosakata yang sesuai untuk merangkai kalimat menjadi paragraf yang padu. Faktor lainnya, yaitu pengetahuan siswa mengenai cara memahami teks pidato yang masih terbatas. Pengetahuan siswa terbatas disebabkan karena kurangnya referensi baik berupa buku teks maupun buku pendukung lainnya. Faktor eksternal, yaitu faktor yang berasal dari luar siswa, misalnya metode pembelajaran yang kurang sesuai dengan materi. Guru masih menggunakan metode ceramah dan diskusi. Selain itu, guru juga belum memaksimalkan media pembelajaran dalam pembelajaran memahami teks pidato. Guru hanya mengunakan model teks yang disuruh dibaca oleh siswa atau juga siswa temannya yang menjdi model pembaca teks sebagai media penyampaian materi. Hal ini membuat siswa cepat bosan saat mengikuti pelajaran Bahasa dan Sastra Indonesia. 
Melihat permasalahan yang muncul, dapat disimpulkan bahwa pembelajaran menyimak teks pidato pada di Kelas IX C MTs Negeri 9 Kuningan perlu mendapatkan perhatian. Untuk itu, perlu adanya inovasi dalam menciptakan interaksi pembelajaran yang kondusif dengan mencari metode pembelajaran yang tepat. Oleh karena itu, penelitian ini bermaksud menerapkan strategi pembelajaran yang akan membantu siswa terampil dalam menyimak teks pidato.

Pada hakikatnya pidato termasuk seni monologika dalam keterampilan berbicara (Keraf, 1988). Monologika hadir pada zaman retorika modern. Dalam ilmu retorika modern, monologika adalah ilmu tentang seni berbicara secara monolog. Dalam monologika hanya satu orang yang berbicara kepada sekelompok orang. Bentuk utama monologika adalah pidato. Ada beberapa faktor yang harus diperhatikan pembicara untuk berpidato. Menurut (Arsjad \& Mukti, 1988), ada dua faktor yang dapat mempengaruhi keefektivan berbicara (termasuk pidato persuasi), yaitu faktor kebahasaan dan faktor nonkebahasaan. Faktor kebahasaan meliputi: (a) ketepatan ucapan dan struktur kalimat; (b) penempatan tekanan, nada, sendi, dan durasi yang sesuai; dan (c) pilihan kata (diksi). Selain faktor kebahasaan, ada juga faktor nonkebahasaan yang meliputi: (a) sikap yang wajar, tenang, dan tidak kaku; (b) kelancaran dalam berbicara; (c) penguasaan materi; (d) gerak-gerik dan mimic yang tepat; (e) kenyaringan suara; (f) kelancaran; dan (g) relevansi atau penalaran. Menurut (Rahkmat, 2009), ada tiga "rukun" yang perlu diperhatikan dalam penyampaian pidato persuasi: kontak; penggunaan suara (paralanguage); penggunaan isyarat dan gerak tubuh (lambang-lambang nonverbal visual). Pada dasarnya menyimak teks pidato diawali dengan menentukan topik atau tema yang akan disimak. Dalam proses menentukan topik inilah siswa mendapatkan ide pokok atau informasi. Informasi yang didapatkan apabila tidak dikelola dengan baik maka siswa tidak dapat menulis rangkuman dengan baik. Pokok-pokok informasi itulah yang nantinya menjadi modal awal dalam menyimak teks pidato.

Proses pembelajaran yang berkualitas dapat tercipta apabila siswa dan guru berpera aktif di dalamnya. Siswa dan guru berinteraksi dalam suatu kegiatan yang disebut dengan pembelajaran serta berlangsung dalam proses pembelajaran. Upaya mewujudkan proses pembelajaran yang efektif dan efisien maka pengajar hendaknya mampu mewujudkan perilaku mengajar secara tepat agar mampu mewujudkan perilaku belajar siswa melalui interaksi pembelajaran yang efektif dalam proses pembelajaran yang kondusif. Oleh karena itu, salah satu usaha yang dapat dilakukan guru adalah merencanakan dan menggunakan model pembelajaran yang dapat mengkondisikan siswa agar belajar secara aktif. Salah satu model pembelajaran yang dapat mengaktifkan siswa adalah metode peta pikiran.

Penggunaan metode peta pikiran dalam menulis teks pidato dipilih karena lebih sesuai diterapkan dibandingkan dengan metode-metode pembelajaran yang lainnya. Hal ini disebabkan metode peta pikiran dibentuk dari gagasan-gagasan yang berbentuk peta pikiran yang dapat disesuaikan dengan struktur teks pidato. Metode peta pikiran adalah metode dengan menggunakan peta rute yang hebat bagi ingatan, memungkinkan penulis menyusun fakta dan pikiran sedemikian rupa sehingga cara kerja alami otak dilibatkan sejak awal, ini berarti mengingat informasi akan lebih mudah dan lebih bisa diandalkan daripada menggunakan teknik pencatatan tradisional (Buzan 2013). Menurut (Darusman, 2014) (Peta Pikiran) adalah metode pembelajaran yang dirancang untuk mengembangkan pengetahuan siswa dengan kegiatan kreatif menyusun ide-ide pokok dari sebuah konsep menjadi sebuah peta pikiran yang mudah dipahami oleh siswa.

Metode peta pikiran bertujuan untuk memetakan pikiran yang ada pada bacaan kemudian pikiran/konsep diilustrasikan oleh siswa dalam bentuk ilustrasi grafis. Teknik pemetaan pikiran dapat digunakan untuk mengajarkan materi menyimak teks pidato. (Huda, 2013) menyatakan bahwa penggunaan peta pikiran, ada beberapa langkah persiapan yang harus dilakukan, antara lain 1) mencatat hasil ceramah dan menyimak poin-poin atau kata kunci-kata kunci dari ceramah tersebut; 2) menunjukkan jaringan-jaringan dan relasi-relasi diantar berbagai poin/ gagasan/ kata kunci ini terkait dengan materi pelajaran; 3) membrainstorming semua hal yang sudah diketahui sebelumnya tentang topik tersebut; 4) merencanakan tahap-tahap awal pemetaaan gagasan dengan memvisualisasikan semua aspek dari topik yang dibahas; 5) menyusun gagasan dan informasi dengan membuatnya bisa diakses pada satu lembar saja; 6) menstimulasi pemikiran dan solusi kreatif atas permasalahan permasalahan yang terkait dengan topik bahasan; dan 7) meninjau pelajaran untuk mempersiapkan tes atau tujuan. (Olivia, 2013) menyatakan bahwa di dalam kegiatan peta pikiran terdapat beberapa komponen yang harus ada, sebagai berikut: 1) Gambar, Otak memanggil gambar lebih baik daripada kata.

Gambar mengaktifkan otak kanan dan lebih "menempel" di otak. Gambar juga bisa membantu mengurangi jumlah kata yang harus diingat; 2) Asosiasi, Dengan menggunakan panah, garis, dan boks, catatan seluruh otak membantu Dengan menggunakan panah, garis, dan boks, catatan seluruh otak membantu anak membuat asosiasi anatar informasi. Ini sangat membantu pemahaman dan mengingat kembali; 3) Warna, Warna mengaktifkan otak kanan dan dapat meningkatkan daya ingat sampai $50 \%$. Otak cenderung melupakan informasi yang membosankan dan mengingat informasi yang disajikan secara 
luar biasa, kreatif atau dengan cara lucu. Catatan seluruh otak membuat anak menggunakan gambar berbeda, warna, bentuk, dan jenis huruf yang bervariasi untuk membuat fakta jadi menonjol; 4) Gambaran besar, Catatan seluruh otak memberi anak gambaran besar bagaimana seluruh poin saling berhubungan satu sama lain dalam satu halaman. Bukankah lebih mudah untuk memahami segala yang dipelajari jika bisa ditunjukkan dalam satu halaman dibanding dua puluh halaman; 5) Kata kunci, Kata kunci merupakan kata-kata tertentu yang penting diingat dan bagaikan "jalan tol" bisa cepat sampai ke otak anak. gunakan hanya kata kunci saat membuat peta pikiran atau catatan seluruh otak untuk memangkas waktu belajar anak sampai $80 \%$. Peta pikiran tentu memberikan manfaat dan kelebihan yang dapat membantu siswa dalam meraih hasil belajar yang lebih baik. Kelebihan dari peta pikiran diantaranya: 1) Dapat memberikan peta pikiran yang dapat memberikan kesan lebih mendalam, sehingga otak lebih mudah mengingat informasi yang ada di dalamnya, (2) Dapat memusatkan perhatian dan meningkatkan pemahaman, (3) Lebih menyenangkan dari pada catatan outlin (Sirojul, 2012).

Penerapan metode peta pikiran akan lebih maksimal apabila dibantu dengan media pembelajaran yang sesuai. Ada berbagai macam media yang dapat digunakan dalam pembelajaran, namun tidak sembarang media dapat digunakan dalam keterampilan berbahasa. Dalam penelitian ini media yang digunakan untuk mendukung proses pembelajaran meyimak teks pidato adalah media kartu tema. Media kartu tema diasumsikan dapat mempermudah siswa dalam menemukan gagasan-gagasan yang selanjutnya dapat dijadikan acuan untuk membuat peta pikiran dalam menulis teks pidato. Hasil penelitian yang dilakukan oleh (Ristanti \& Arianto, 2019) menyatakan bahwa pemanfaatan media "Flash Card" membantu siswa untuk memahami dengan baik, merangkul subtopik secara memadai, dan membantu siswa memperoleh nilai yang lebih baik. Kemudian penelitian yang dilakukan oleh (Aliputri, 2018) menyatakan bahwa penggunaan media kartu gambar dapat meningkatkan hasil belajar IPS tentang kegiatan ekonomi bagi siswa kelas IV SD N Wulung 1 Blora.

Penelitian yang dilakukan oleh (Bunga, 2018) menyatakan bahwa terdapat peningkatan dalam perencanaan, pelaksanaan, dan hasil evaluasi keterampilan memproduksi teks cerpen menggunakan model pembelajaran peta pikiran (mind map) pada siswa kelas XI AP 2 SMKN 3 Pontianak tahun pembelajaran 2015/2016. Kemudian penelitian yang dilakukan oleh (Rahman \& Chan, 2016) yang menyatakan bahwa teknik peta pikiran dapat meningkatkan kemampuan menulis siswa, dengan ditunjukkan peningkatan nilai siswa setelah menerapkan teknik peta pikiran, 25 siswa $(92,6 \%)$ mendapat nilai sangat baik dan 2 lainnya $(7,43 \%)$ mendapat nilai baik.

Oleh karena itu, digunakan metode peta pikiran dengan media kartu tema guna meningkatkan keterampilan menulis teks pidato siswa. Dengan metode dan media ini, siswa diharapkan dapat meningkatkan keterampilan menulis teks pidato dengan cara guru menyajikan topik/tema dalam bentuk kartu tema dan penulisan teks pidato menggunakan metode peta pikiran. Penyajian permasalahan dalam bentuk kartu tema dimaksudkan agar lebih menarik dan siswa tidak kesulitan mencari ide untuk tulisannya. Dari permasalahan yang terdapat di dalam kartu itu, siswa menentukan gagasan yang akan dibuat teks pidato utuh. Metode peta pikiran digunakan agar gagasan-gagasan siswa dapat dipetakan, sehingga siswa tidak kesulitan mengembangkan idenya menjadi sebuah teks pidato.

\section{Metode}

Penelitian ini menggunakan jenis penelitian tindakan kelas (PTK) yang didasari pada keinginan peneliti untuk memperbaiki praktek dan hasil belajar. Prosedur PTK ini didesain untuk 3 siklus, dimana tiap-tiap siklus dilaksanakan dalam 3 (tiga) kali tatap muka. Rencana tindakan pada masing- masing siklus dalam PTK ini dibagi dalam 4 (empat) kegiatan yaitu:(1) Perencanaan, (2) Tindakan (3) Observasi dan Evaluasi dan (4) Analisis dan Refleksi. Lokasi penelitian adalah di MTs Negeri 9 Kuningan di Jalan Raya Sako Dua Kecamatan Kuningan Kabupaten Kuningan, Provinsi Jawa barat . Subjek penelitian adalah siswa kelas IX C MTs Negeri 9 Kuningan yang berjumlah 38 orang, terdiri dari 19 orang siswa laki-laki dan 19 orang siswa perempuan. Data dari penelitian ini berupa hasil observasi guru, observasi siswa , angket dan hasil fortopolio atau kertas jawaban soal dari 38 orang siswa. Sumber data untuk memperoleh data penelitian ini adalah siswa kelas IX C MTs Negeri 9 Kuningan semester ganjil tahun pelajaran 2019/2020. Data penelitian diambil dengan cara sebagai berikut : a) Data hasil penelitian diambil dari tes hasil belajar yakni analisis fortopolio siswa; b) Data tentang proses belajar mengajar diambil dari observasi guru dan siswa; c) Data refleksi diambil dari jurnal dibuat guru; d) Data tentang efektifitas teknik pembelajaran dari angket dibagikan kepada siswa. Waktu penelitian penyelenggaraan penelitian ini pada semester Ganjil tahun pelajaran 2019 /2020 bulan September sampai Oktober 2019.

Untuk mengetahui kemampuan awal siswa, maka dilaksanakan kegiatan pra tindakan dan observasi yakni: a) Pra tindakan, Dimana siswa diberikan angket untuk mengukur keterampilan menyimak siswa. Daftar pertanyaan diberikan kepada siswa mengetahui gambaran permasalahan yang 
dihadapi dalam pembelajaran menyimak. Siswa menjawab pertanyaan dengan pilihan jawaban yang sudah tersedia dengan keadaan yang dihadapi; b) Observasi guru dan observasi siswa, Lembar ini digunakan untuk memperoleh data tentang kegiatan yang dilakukan oleh guru dalam proses pembelajaran dengan permasalahan yang terjadi, Lembar ini digunakan untuk memperoleh data dari siswa yan sedang melakukan tindakan keterampilan. Penelitian mencatat segala permasalahan yang terjadi baik siswa yang ikut terlibat aktif maupun yang tidak aktif.

Prosedur penelitian kelas dilaksanakan sesuai dengan perubahan yang ingin dicapai untuk dapat melihat kemampuan siswa menentukan hal-hal pokok dalam pidato dan ceramah, kemampuan siswa menentukan isi pidato dan ceramah, kemampuan siswa menyimpulkan pesan pidato serta kemampuan siswa mengomentari isi pidato dengan alasan yang logis dan bahasa yang santun, maka diadakan evaluasi dari hasil evalusi diadakan analisis dan refleksi sehingga dapat dicarikan solusi untuk mengatasi masalah. Pelaksanaan ini dilakukan dengan menggunakan tiga siklus yang masing-masing terdiri dari perencanaan, pelaksanaan, pengamatan dan refleksi

\section{Hasil dan Pembahasan}

\section{Siklus Pertama \\ Perencanaan}

Dalam perencanaan meliputi: 1) Topik pembelajaran: menyimak pidato dengan judul "Memilih Calon Peminpin Umat"; 2) Tujuan pembelajaran: setelah salah satu siswa membacakan pidato yang berjudul "Memilih Calon Peminpin Umat ", siswa dapat: Menyimak pidato persuasif, Menentukan hal-hal pokok dalam pidato, Menentukan isi pidato, Menyimpulkan pesan pidato, Mengomentari isi pidato dengan alasan yang logis dan bahasa yang santun, Menjawab pertanyaan-pertanyaan.

\section{Pelaksanaan}

Dalam pelaksanaan meliputi: 1) Guru memasuki ruang kelas kemudian memberi salam, mengabsen, 2) Guru memulai pembelajaran dengan menyebutkan judul dan tujuan pembelajaran dan memberikan apersepsi pembelajaran; 3) Guru menjelaskan langkah-langkah menyimak dengan teknik Peta pikiran; 4) Guru mnyuruh salah dua siswa membacakan pidato secara bergantuan dan siswa yang lain menyimak pidato; 5) Setelah siswa menyimak pidato dan ceramah secara bergantian, siswa menentukan hal-hal pokok dalam pidato, menentukan isi pidato dan ceramah, menyimpulkan pesan-pesan pidato, serta mengomentari isi pidato dengan alasan yang logis dan bahasa yang santun; 6) Siswa mengumpulkan hasil jawaban;7) Guru menutup pembelajaran dengan refleksi dari hasil pembelajaran.

Pada akhir penelitian diharapkan keterampilan menyimak siswa terhadap pidato mengalami peningkatan dengan kriteria sebagai berikut: 1) Sekurang-kurangnya 65\% siswa memiliki kemampuan menentukan hal-hal pokok dalam pidato dan ceramah; 2) Sekurang-kurangnya 65\% siswa memiliki kemampuan menentukan isi pidato dan ceramah; 3) Sekurang-kurangnya 65\% siswa memiliki kemampuan menyimpulkan pesan pidato dan ceramahSekurang-kurangnya 65\% siswa memiliki kemampuan memberikan komentar dengan alasan yang logis dan bahasa yang santun tentang isi pidato.

Tahap pelaksanaan siklus I untuk kriteria pertama dapat digambarkan sebagai berikut: Dalam analisis hasil fortopolio datayang diperoleh dengan instrumen pengukur peningkatan kemampuan menentukan hal-hal pokok dalam pidato mencapai 49,20\%ini berarti belum sesuai dengan kriteria yang telah ditetapkan, dapat disimpulkan bahwa apa yang telah direncanakan pada kritera pertama belum bisa direalisasikan secara penuh sesuai dengan kriteria yang telah ditetapkan.

Tahap pelaksanaan siklus I untuk kriteria kedua dapat digambarkan sebagai berikut: Berdasarkan analisis fortopolio siswa dapat direfleksikan, maka diketahui persentase hasil pencapai terhadap kriteria kedua yakni kemampuan menentukan isi pidato mencapai 49,60\% dapat disimpulkan bahwa siswa belum mampu/ berhasil untuk menentukan isi pidato sesuai dengan kriteria yang telah ditetapkan.

Tahap pelaksanaan siklus I untuk kriteria ketiga dapat digambarkan sebagai berikut: Berdasarkan analisis data dari hasil Fortopolio siswa, dapat direfleksikan, maka diketahui persentase hasil pencapaian terhadap kriteria ketiga yakni kemampuanm menyimpulkan pesan isi pidato mencapai 50,68\% dapat disimpulkan bahwa siswa belum mampu/berhasil untuk menyimpulkan isi pidato sesuai dengan kriteria yang telah ditetapkan.

Tahap pelaksanaan siklus I untuk kriteria keempat dapat digambarkan sebagai berikut: Berdasarkan analisis data dari hasilfortopolio siswa, dapat direfleksikan, maka diketahui persentase hasil pencapaian terhadap kriteria keempat yakni kemampuan mengomentari isi pidato dengan alasan yang logis dan bahasa yang santun mencapai 52,80\%, maka dapat disimpulkan bahwasiswa belum berhasil / mampu untuk mengomentari isi pidato dengan alasan yang logis dan bahasa yang santun dengan kriteria yang telah ditetapkan. 


\section{Pengamatan}

Berdasarkan hasil observasi terhadap berbagai instrumen yang digunakan dapat diuraikan sebagai berikut: 1) Lewat observasi dalam proses belajar mengajar pada siklus I, bahwa kelas IX C yahg ikut aktif $50 \%$ kegiatan pengambilan data ini dilakukan oleh mitra (observer) yang telah diamati berarti hasil observer siswa masih kurang sekali; 2) Lewat observasi guru dalam proses belajar mengajar pada siklus I, bahwa guru yang melaksanakan tindakan dikategorikan baik yakni mencapai 83\% sesuai dengan hasil observer guru mitra dengan kriteria yang telah ditetapkan; 3) Berdasarkan hasil fortopolio siswa, dapat disimpulkan hasil fortopolio siswa belum memenuhi kriteria yang telah ditetapkan.

\section{Refleksi}

Dengan mengacu pada instrumen pengukur tingkat ketercapaiankemampuan menentukan hal-hal pokok dalam pidato mencapai49,20\%,kemampuan menentukan isi pidato mencapai 49,60\% kemampuan menyimpulkan isi pidato mencapai 50,68\%, kemampuan mengomentari isi pidato dengan alasan yang logis dan bahasa yang santun mencapai 52,80\%, hal ini dapat disimpulkan bahwa pada siklus I belum mencapai kriteria yang telah ditetapkan, harus dilanjutkan pada siklus berikutnya.

\section{Siklus Kedua \\ Perencanaan}

Langkah-langkah tingkat perencanaan dalam siklus II kegiatan yang dilakukan sama dengan siklus. Tahap pelaksanaan pada siklus II untuk kriteria pertama dapat digambarkan sebagai berikut: Berdasarkan data yang diperoleh melalui analisis fortopolio terhadap kemampuan menentukan halhalpokok dalam pidato mencapai 67,20\% ini berarti sudah sesuai dengan kriteria yang telah ditetapkan, dari data yang diperoleh dapatdisimpulkan bahwa apa yang telah direncanakan pada kriteria pertama bisa direalisasikan secara penuh sesuai dengan kriteria yang telah ditetapkan.

Tahap pelaksanaan pada siklus II untuk kriteria kedua dapat digambarkan sebagai berikut : Berdasarkan hasil analisis fortopolio siswa, terhadap kemampuan menentukan isi pidato mencapai $68,80 \%$,sehingga dapat disimpulkan bahwa siswa telah mampu / berhasil untuk menentukan isi pidato sesuai dengan kriteria yang telah ditetapkan.

Tahap pelaksanaan pada siklus II untuk kriteria ketiga dapatdigambarkan sebagai berikut : Berdasarkan hasil analisis fortopolio siswa terhadap kemampuan siswa menyimpulkan pesan pidato mencapai 70,40\%, sehingga dapat disimpulkan bahwa siswa telah mampu / berhasil untuk menyimpulkan pesan pidato sesuai dengan kriteria yang telah ditetapkan.

Tahap pelaksanaan pada siklus II untuk kriteria keempat dapatdigambarkan sebagai berikut : Berdasarkan hasil analisis fortofolio siswa terhadap kemampuan mengomentari isi pidato dengan alasanyang logis dan bahasa yang santun mencapai 65,20 \%, ini berarti dapat disimpulkan bahwa siswa telah mampu / berhasil untuk mengomentari isi pidato sesuai dengan kriteria yang telah ditetapkan.

\section{Pengamatan}

Berdasarkan hasil observasi terhadap siswa, observasi guru dan analisis fortopolio siswa dapat diuraikan sebagai berikut: 1) Lewat observasi siswa dalam proses belajar mengajar pada siklus II, bahwa kelas IX C MTs Negeri 9 Kuningan yang ikut terlibat aktif dalam belajar 65\% kegiatan pengambilan data ini dilakukan oleh mitra (observer) yang telah diamati berarti hasil observer siswa baik. 2) Lewat observasi guru dalam proses belajar mengajar pada siklusII, bahwa guru yang melaksanakan tindakan atau proses mengajar dikategorikan baik yakni mencapai skor 100\% sesuai denganhasil observer guru mitra dengan kriteria yang telah ditetapkan. 3) Berdasarkan hasil fortopolio siswa, dapat disimpulkan bahwa hasil fortopolio siswa telah memenuhi kriteria yang telah ditetapkan.

\section{Refleksi}

Dengan mengacu pada instrumen pengukur tingkat ketercapaian kemampuan siswa menentukan hal-hal pokok dalam pidato mencapai $67,20 \%$, kemampuan siswa menentukan isi pidato mencapai $68,80 \%$, kemampuan siswa menyimpulkan pesan isi pidato mencapai 70,40\%, kemampuan siswa mengomentari isi pidato dengan alasan yang logis dan bahasa yang santun mencapai 65,20\%.

Dari hasil rekapitulasi kegiatan tahap II, hal ini dapat disimpulkan bahwa pada siklus II, telah meningkat kemampuan siswa dari siklus I, berarti sudah memenuhi kriteria yang telah ditetapkan.

\section{Siklus Ketiga}

Pelaksanaan tindakan pada siklus III ini menggunakan proseduryang sama dengan siklus-siklus sebelumnya yaitu perencanaan, pengamatan dan refleksi. Tindakan siklus ketiga ini hanya merupakan 
pemantapan dan penekanan kembali atas hasil yang sudah diperoleh pada siklus kedua yang dianggap telah memenuhi kriteria yang telah ditentukan.

Setelah selesai memberikan tindakan dari setiap siklusnya dapat dilihat adanya perubahan hasil belajar, yaitu hasil belajar siswa meningkat dari satu siklus I hingga ke siklus II yang cukup signifikan.

\section{Perolehan Hasil Belajar Siswa pada siklus I, II dan Siklus III}

Dari kegiatan pembelajaran Bahasa Indonesia pada materi "Menyimak pidato" dengan menerapkan Model Peta Pikirandi kelas Menyimak pidato diperoleh hasil belajar belajar siswa pada tiap siklusnya mengalami peningkatan, yaitu dapat dilihat pada Tabel 1 berikut.

Tabel 1. Nilai Evaluasi Belajar Siswa pada setiap SIklus

\begin{tabular}{|c|c|c|c|c|}
\hline \multirow{2}{*}{ No } & \multirow{2}{*}{ Nama } & \multicolumn{3}{|c|}{ Nilai Evaluasi } \\
\hline & & Siklus I & Siklus II & Siklus III \\
\hline 1 & Aditia Firmansah & 60 & 70 & 90 \\
\hline 2 & Aditiya Saputra & 60 & 70 & 80 \\
\hline 3 & Agung Gunawan Wijaya & 60 & 80 & 80 \\
\hline 4 & Ahmad Mahendra Setiawan & 60 & 70 & 90 \\
\hline 5 & Aldi & 60 & 70 & 80 \\
\hline 6 & Alin Rahma Rizkia & 60 & 70 & 80 \\
\hline 7 & Amelia Azzahra & 60 & 70 & 90 \\
\hline 8 & Anugrah Sejati & 60 & 70 & 80 \\
\hline 9 & Azka Ulal Yakin & 60 & 70 & 90 \\
\hline 10 & Dede Nuryaman & 70 & 80 & 80 \\
\hline 11 & Denia Jalianti & 60 & 70 & 90 \\
\hline 12 & Desi Eviyanti & 50 & 60 & 70 \\
\hline 13 & Dewi Pratiwi & 60 & 70 & 70 \\
\hline 14 & Didin Wahyudin & 50 & 60 & 70 \\
\hline 15 & Fiqram Abrar Muzadi & 50 & 60 & 90 \\
\hline 16 & Indah Widia Sapitri & 60 & 60 & 80 \\
\hline 17 & Jujun Junansah & 60 & 70 & 80 \\
\hline 18 & Muhamad Ibnu Muhibat & 60 & 70 & 80 \\
\hline 19 & Muhamad Rafli & 50 & 60 & 70 \\
\hline 20 & Muhammad Robbiyansyah Suhandi Putra & 50 & 60 & 80 \\
\hline 21 & Muhammad Sihabudin & 70 & 80 & 80 \\
\hline 22 & Rendi Herdiansyah & 50 & 60 & 70 \\
\hline 23 & Reni Julianti & 50 & 60 & 70 \\
\hline 24 & Rina Rosalina & 60 & 70 & 70 \\
\hline 25 & Ripky Meiyandri & 70 & 80 & 80 \\
\hline 26 & Riska Novitasari & 40 & 60 & 70 \\
\hline 27 & Rivansyah & 50 & 60 & 80 \\
\hline 28 & Rosah Amelia & 50 & 60 & 70 \\
\hline 29 & Rosi Tamara & 50 & 60 & 70 \\
\hline 30 & Sahrul Fadilah & 60 & 70 & 80 \\
\hline 31 & Sindi & 50 & 60 & 70 \\
\hline 32 & Siti Julaeha & 60 & 70 & 80 \\
\hline 33 & Siti Lisnawati Nurjanah & 50 & 60 & 80 \\
\hline 34 & Siti Mutiara Lailatul Fajriah & 70 & 80 & 80 \\
\hline 35 & Siti Nurhasanah & 50 & 60 & 70 \\
\hline 36 & Siti Nurhayati & 50 & 60 & 70 \\
\hline 37 & Tria Ratnanengsih & 60 & 70 & 70 \\
\hline 38 & Zainul Mutaqin & 70 & 80 & 80 \\
\hline & Jumlah & 2410 & 2860 & 3330 \\
\hline & Rata-Rata & 56.05 & 66,52 & 77.45 \\
\hline
\end{tabular}

Tingkat pencapaian penguasaan materi pembelajran Bahasa Indonesia mengalami peningkatan pada awal sebelum adanya tindakan kelas rata-rata 56,05, pada siklus I setelah adanya penelitian tindakan kelas mencapai rata-rata 66,52, dan pada siklus II mengalami peningkatan yang cukup signifikan mencapai rata-rata 77,45 . 


\section{Perolehan hasil evaluasi belajar kelompok pada siklus I dan II}

Belajar kelompok diskusi pada proses perbaikan pembelajaran. setelah diadakan evaluasi diperoleh suatu hasil atau temuan, juga mengalami peningkatan 2

Tabel 2. Nilai Evaluasi Belajar Kelompok pada Siklus I dan II

\begin{tabular}{ccccc}
\hline \multirow{2}{*}{ No } & \multirow{2}{*}{ Nama Kelompok } & \multicolumn{2}{c}{ Nilai Evaluasi } & \multirow{2}{*}{ Keterangan } \\
\cline { 2 - 4 } & I & 70 & Siklus II & Naik \\
\hline 1 & II & 70 & 80 & Naik \\
2 & III & 70 & 90 & Naik \\
4 & IV & 70 & 80 & Naik \\
5 & V & 70 & 80 & Naik \\
6 & VI & 80 & 90 & Naik \\
\hline & Jumlah & $\mathbf{4 3 0}$ & 90 & \\
\hline & Rata-Rata & $\mathbf{7 1 , 7}$ & $\mathbf{5 1 0}$ & \\
\hline
\end{tabular}

Hasil evaluasi dari kerja kelompok dalam pembahasan materi pada siklus I memperoleh rata-rata 75 dan pada siklus II naik menjadi 86,67.

Dari data hasil pembahasan terhadap hasil belajar siswa dalam belajar dan grafik" secara rinci dapat dikemukakan sebagai berikut: 1) Hasil awal menunjukkan skor rata-rata: 56,05, 2) Hasil pada siklus I naik menjadi skor rata-rata: 66,52, 3) Hasil pada siklus II naik menjadi skor rata-rata: 77,45.

Dengan demikian, meningkatnya nilai dari hasil evaluasi pembelajaran Menyimak pidato di kelas IX C MTs Negeri 9 Kuningan" pada tiap siklusnya, berarti pemahaman siswa Kelas IX C MTs Negeri 9 Kuningan terhadap materi tersebut menunjukkan adanya peningkatan yang cukup signifikan. Hal ini dapat dilihat melalui diagram grafik.

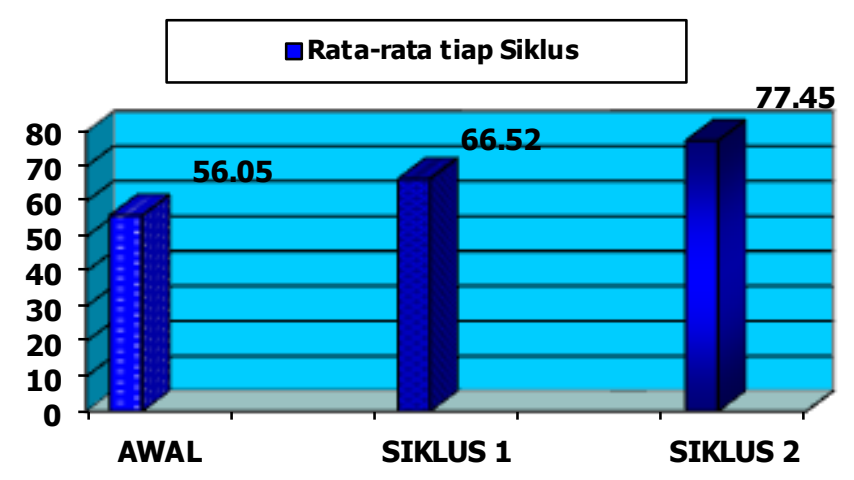

Gambar 1. Diagram Grafik Peningkatan Pemahaman Materi “Menyimak Pidato"

\section{Hasil observasi aktivitas belajar siswa}

Selama kegiatan proses perbaikan pembelajaran Bahasa Indonesia pada materi " Menyimak Pidato" di kelas IX C MTs Negeri 9 Kuningan pada tiap siklusnya mengalami peningkatan, yaitu:

a. Siswa yang bisa menjawab pertanyaan atau permasalahan meningkat.

b. Siswa yang menyampaikan pendapat meningkat.

c. Siswa yang memperhatikan secara aktif meningkat.

d. Siswa yang mengajukan pertanyaan atau mengungkapkan permasalahan cukup meningkat.

e. Siwa yang bekerja dan belajar secara aktif.

Dari hasil penelitian dan pembahasan di atas menunjukkan bahwa hipotesis tindakan terbukti, yaitu dengan menerapkan Model Peta Pikiran dapat meningkatkan pemahaman siswa dalam belajar Bahasa Indonesia dan hasil belajar siswa Kelas IX C MTs Negeri 9 Kuningan. Menurut (Hadi 2017) Belajarmengajar merupakan kegiatan yang mengaktifkan siswa dalam membangun makna atau pemahaman. Menurut (Arsjad \& Mukti, 1988), ada dua faktor yang dapat mempengaruhi keefektivan berbicara (termasuk pidato persuasi), yaitu faktor kebahasaan dan faktor nonkebahasaan. Faktor kebahasaan meliputi: (a) ketepatan ucapan dan struktur kalimat; (b) penempatan tekanan, nada, sendi, dan durasi 
yang sesuai; dan (c) pilihan kata (diksi). Selain faktor kebahasaan, ada juga faktor nonkebahasaan yang meliputi: (a) sikap yang wajar, tenang, dan tidak kaku; (b) kelancaran dalam berbicara; (c) penguasaan materi; (d) gerak-gerik dan mimic yang tepat; (e) kenyaringan suara; (f) kelancaran; dan (g) relevansi atau penalaran. Menurut (Rahkmat, 2009), ada tiga "rukun" yang perlu diperhatikan dalam penyampaian pidato persuasi: kontak; penggunaan suara (paralanguage); penggunaan isyarat dan gerak tubuh (lambang-lambang nonverbal visual)

Penggunaan metode peta pikiran dalam menulis teks pidato dipilih karena lebih sesuai diterapkan dibandingkan dengan metode-metode pembelajaran yang lainnya. Hal ini disebabkan metode peta pikiran dibentuk dari gagasan-gagasan yang berbentuk peta pikiran yang dapat disesuaikan dengan struktur teks pidato. Metode peta pikiran adalah metode dengan menggunakan peta rute yang hebat bagi ingatan, memungkinkan penulis menyusun fakta dan pikiran sedemikian rupa sehingga cara kerja alami otak dilibatkan sejak awal, ini berarti mengingat informasi akan lebih mudah dan lebih bisa diandalkan daripada menggunakan teknik pencatatan tradisional (Buzan 2013). Menurut (Darusman, 2014) (Peta Pikiran) adalah metode pembelajaran yang dirancang untuk mengembangkan pengetahuan siswa dengan kegiatan kreatif menyusun ide-ide pokok dari sebuah konsep menjadi sebuah peta pikiran yang mudah dipahami oleh siswa.

Metode peta pikiran bertujuan untuk memetakan pikiran yang ada pada bacaan kemudian pikiran/konsep diilustrasikan oleh siswa dalam bentuk ilustrasi grafis. Teknik pemetaan pikiran dapat digunakan untuk mengajarkan materi menyimak teks pidato. (Darusman, 2014) menyatakan bahwa penggunaan peta pikiran, ada beberapa langkah persiapan yang harus dilakukan, antara lain 1) mencatat hasil ceramah dan menyimak poin-poin atau kata kunci-kata kunci dari ceramah tersebut; 2) menunjukkan jaringan-jaringan dan relasi-relasi diantar berbagai poin/ gagasan/ kata kunci ini terkait dengan materi pelajaran; 3) membrainstorming semua hal yang sudah diketahui sebelumnya tentang topik tersebut; 4) merencanakan tahap-tahap awal pemetaaan gagasan dengan memvisualisasikan semua aspek dari topik yang dibahas; 5) menyusun gagasan dan informasi dengan membuatnya bisa diakses pada satu lembar saja; 6) menstimulasi pemikiran dan solusi kreatif atas permasalahan permasalahan yang terkait dengan topik bahasan; dan 7) meninjau pelajaran untuk mempersiapkan tes atau tujuan. Olivia (2013:xxi-xxii) menyatakan bahwa di dalam kegiatan peta pikiran terdapat beberapa komponen yang harus ada, sebagai berikut: 1) Gambar, Otak memanggil gambar lebih baik daripada kata.

Gambar mengaktifkan otak kanan dan lebih "menempel" di otak. Gambar juga bisa membantu mengurangi jumlah kata yang harus diingat; 2) Asosiasi, Dengan menggunakan panah, garis, dan boks, catatan seluruh otak membantu Dengan menggunakan panah, garis, dan boks, catatan seluruh otak membantu anak membuat asosiasi anatar informasi. Ini sangat membantu pemahaman dan mengingat kembali; 3) Warna, Warna mengaktifkan otak kanan dan dapat meningkatkan daya ingat sampai $50 \%$. Otak cenderung melupakan informasi yang membosankan dan mengingat informasi yang disajikan secara luar biasa, kreatif atau dengan cara lucu. Catatan seluruh otak membuat anak menggunakan gambar berbeda, warna, bentuk, dan jenis huruf yang bervariasi untuk membuat fakta jadi menonjol; 4) Gambaran besar, Catatan seluruh otak memberi anak gambaran besar bagaimana seluruh poin saling berhubungan satu sama lain dalam satu halaman. Bukankah lebih mudah untuk memahami segala yang dipelajari jika bisa ditunjukkan dalam satu halaman dibanding dua puluh halaman; 5) Kata kunci, Kata kunci merupakan kata-kata tertentu yang penting diingat dan bagaikan "jalan tol" bisa cepat sampai ke otak anak. gunakan hanya kata kunci saat membuat peta pikiran atau catatan seluruh otak untuk memangkas waktu belajar anak sampai $80 \%$. Peta pikiran tentu memberikan manfaat dan kelebihan yang dapat membantu siswa dalam meraih hasil belajar yang lebih baik. Kelebihan dari peta pikiran diantaranya: 1) Dapat memberikan peta pikiran yang dapat memberikan kesan lebih mendalam, sehingga otak lebih mudah mengingat informasi yang ada di dalamnya, (2) Dapat memusatkan perhatian dan meningkatkan pemahaman, (3) Lebih menyenangkan dari pada catatan outlin (Sirojul, 2012).

Berdasarkan uraian-uraian pada bab sebelumnya dapat ditarik kesimpulan sebagai berikut: 1) pelaksanaan tindakan sebagai upaya meningkatkan keterampilan menyimak siswa kelas IX C MTs Negeri 9 Kuningan tahun pelajaran 2019/ 2020 semester ganil dengan teknik peta pkiran telah dapat meningkatkan prestasi keterampilan menyimak siswa. Siswa lebih mudah melakukan kegiatan menyimak. Berdasarkan data hasil penelitian yang telah penulis lakukan maka dapat disimpulkan sebagai berikut (a) kemampuan siswa menentukan hal-hal pokok pidato dan ceramah dari 49,20\% meningkat menjadi 76,80\%.(b) kemampuan siswa menentukan isi pidato dari 49,60\% meningkat menjadi 76,00\%.(c) kemampuan siswa menyimpulkan pesan isi pidato dari 50,68\% meningkat menjadi 74,80\%.(d) kemampuan siswa mengomentari isi pidato dan ceramah dengan alasan-alasan yang logis dan bahasa yang santun dari 52,80\% meningkat menjadi 71,40\%; 2) sikap siswa dalam menyimak umumnya lebih baik dan benar. Para siswa dapat menyimak secara lebih berkosentrasi karena adanya teknik peta pikiran; 3) kompetensi guru sebagai hasil pelaksanaan kegiatan belajar mengajar keterampilan menyimak denga kata 
kunci antara lain sebagai berikut (a) guru mempersiapkan pembelajaran sebaik mungkin. (b) guru mengajar secara sistematis. (c) guru merancang teknik tanya jawab. (d) gurudapat membangkitkan motivasi siswa mengikuti pembelajaran melalui teknik pujian terhadap siswa yang telah dapat menunjukkan prestasi secara profesional.

\section{Simpulan dan Saran}

Berdasarkan uraian-uraian pada bab sebelumnya dapat ditarik kesimpulan sebagai berikut: 1) pelaksanaan tindakan sebagai upaya meningkatkan keterampilan menyimak siswa kelas IX C MTs Negeri 9 Kuningan tahun pelajaran 2019/ 2020 semester ganil dengan teknik peta pkiran telah dapat meningkatkan prestasi keterampilan menyimak siswa. Siswa lebih mudah melakukan kegiatan menyimak. Berdasarkan data hasil penelitian yang telah penulis lakukan maka dapat disimpulkan sebagai berikut (a) kemampuan siswa menentukan hal-hal pokok pidato dan ceramah dari 49,20\% meningkat menjadi 76,80\%.(b) kemampuan siswa menentukan isi pidato dari $49,60 \%$ meningkat menjadi $76,00 \%$.(c) kemampuan siswa menyimpulkan pesan isi pidato dari 50,68\% meningkat menjadi $74,80 \%$.(d) kemampuan siswa mengomentari isi pidato dan ceramah dengan alasan-alasan yang logis dan bahasa yang santun dari 52,80\% meningkat menjadi 71,40\%;2) sikap siswa dalam menyimak umumnya lebih baik dan benar. Para siswa dapat menyimak secara lebih berkosentrasi karena adanya teknik peta pikiran; 3) kompetensi guru sebagai hasil pelaksanaan kegiatan belajar mengajar keterampilan menyimak denga kata kunci antara lain sebagai berikut (a) guru mempersiapkan pembelajaran sebaik mungkin. (b) guru mengajar secara sistematis. (c) guru merancang teknik tanya jawab. (d) gurudapat membangkitkan motivasi siswa mengikuti pembelajaran melalui teknik pujian terhadap siswa yang telah dapat menunjukkan prestasi secara profesional.

Berdasarkan kesimpulan di atas pelaksanaan pembelajaran keterampilan menyimak siswa kelas IX C MTs Negeri 9 Kuningan berhasil dan membawa dampak positif dengan menggunakan peta pikiran. Oleh sebab itu materi dapat dikembangkan lagi dengan mencari bahan simakan yang lain, contohnya puisi, ceramah dan lain-lain, sumber simakan dapat dikembangkan ke sumber lain yang sederhana sehingga pembelajaran menyimak dapat dilakukan oleh siapapun, dimanapun, kapanpun, misalnya simakan di televisi, di radio, dan sebagainya, pembelajaran keterampilan menyimak hendaknya dapat dikembangkan dengan teknik lainnya misalnya, bisik berantai, dengar tulis ( dikte ), simpan bilang dan sebagainya.

\section{Daftar Rujukan}

Aliputri, D. H. (2018). Penerapan Model Pembelajaran Kooperatif Tipe Make A Match Berbantuan Kartu Bergambar Untuk Meningkatkan Hasil Belajar Siswa. Jurnal Bidang Pendidikan Dasar, 2(1A), 70-77. https://doi.org/10.21067/jbpd.v2i1a.2351

Arsjad, Maidar g. 1988. Pembinaan Kemampuan Berbicara Bahasa Indonesia. Jakarta: Depdiknas.

Bunga, J. (2018). Penerapan Model Pembelajaran Peta Pikiran Untuk Meningkatkan Keterampilan Menulis Cerpen Siswa Smk. Jurnal Edukasi Khatulistiwa, 1(2). https://doi.org/http://dx.doi.org/10.26418/ekha.v1i2.29520

Darusman, Rijal. (2014). Penerapan Metode Mind Mapping (Peta Pikiran) untuk Meningkatkan Kemampuan Berpikir Kreatif Matematik Siswa SMP. Jurnal Ilmiah Program Studi Matematika STKIP Siliwangi Bandung, Vol 3, No.2, Hal. 164-173. Tersedia Pada: http://ejournal.stkipsiliwangi.ac.id/index.php/infinity/article/view/61.

Djuanda, D. (2008). Pembelajaran Keterampilan Berbahasa Indonesia di Sekolah Dasar. Bandung: Pustaka Latifah.

Hadi, Saptono. (2017). Story-telling: Upaya Meningkatkan Daya Simak dalam Keterampilan Menyimak Interaktif Berbahasa. BRILLIANT: Jurnal Riset dan Konseptual Volume 2 Nomor 2, Hal. 163-177. Tersedia Pada: http://eprints.ums.ac.id/28102/11/NASKAH_PUBLIKASI.pdf.

Huda, Miftakhul. (2013). Model-model Pengajaran dan Pembelajaran.Yogyakarta: Pustaka Pelajar.

Keraf, G. (2004). Diksi dan Gaya Bahasa. Jakarta: PT Gramedia Pustaka Utama.

Moeliono, A.M, dkk. (2013). Kamus Besar Bahasa Indonesia. Jakarta : Pusat Pembinaan dan Pengembangan Bahasa.

Olivia, Femi. (2013). 5-7 Menit Asyik Mind Mapping Kreatif. Jakarta: PT Elex Media Komputindo. 
Pebriana, Ulifatus, Dyah Woro Wirastri Ekowati, Frendy Aru Fantiro. (2017). Peningkatan Keterampilan Menyimak Melalui Model Pembelajaran Artikulasi dan Media Boneka Tangan pada Pembelajaran Tematik Kelas 1 SDN Pejok Ii Kedungadem Bojonegoro. Jurnal Pemikiran dan Pengembangan SD, Volume 5, Nomor 2, Hal. 766-772. Tersedia Pada: http://ejournal.umm.ac.id/index.php/jp2sd/article/view/4826.

Rahman, I., \& Chan, D. M. (2016). Penerapan Metode Peta Pikiran Dalam Menulis Esai Mahasiswa Semester V Stkip Ydb Lubuk Alung. Ta'dib, 19(1), 97. https://doi.org/10.31958/jt.v19i1.454

Rakhmat, Jalaludin. 1994. Retorika Modern Pendekatan Praktis. Bandung: PT Remaja Rosdakarya.

Ristanti, F. F., \& Arianto, F. (2019). Flash Card Media Utilization To Improve Student Activity and Learning Outcomes of Fauna Distribution Subtopic in Class XI IPS I SMA Xin Zhong Surabaya. Geosfera Indonesia, 4(2), 90. https://doi.org/10.19184/geosi.v4i2.9968

Satria, Tio Gusti. (2017). Meningkatkan Keterampilan Menyimak Melalui Pendekatan Saintifik pada Anak Kelas IV Jakarta Barat. Jurnal PGSD: Jurnal Ilmiah Pendidikan Guru Sekolah Dasar, 10 (2), Hal.114120. Tersedia Pada: https://ejournal.unib.ac.id/index.php/pgsd/article/view/3339.

Sirojul, A. (2012). Pengaruh Teknik Mencatat Peta Pikiran Dalam Pembelajaran Kooperatif Tipe Stad Terhadap Hasil Belajar Siswa Keas X MAN 1 Malang. Skripsi. Malang. Universitas Negeri Malang.

Suharsini, Suhardjono, dan Sapardi. (2006). Penelitian Tindakan Kelas. Jakarta:Bumi Aksara.

Tarigan, G.H. (1996). Menyimak Sebagai Suatu Keterampilan Berbahasa. Bandung : Angkasa.

Tarigan, Henry Guntur. (1982). Menulis Sebagai Suatu Keterampilan Berbahasa.Bandung: Angkasa.

Zakiyah M, Siti Ayu, Rustono WS, Hodidjah. (2018). Pengaruh Teknik Pemetaan Pikiran (Mind Mapping) terhadap Keterampilan Menulis Karangan Narasi Siswa. 2018. Pedadidaktka: Jurnal Ilmiah Pendidikan Guru Sekolah Dasar, Vol. 5, No. 1, Hal. 338-348. Tersedia Pada: https://ejournal.upi.edu/index.php/pedadidaktika/article/view/7455. 